\title{
Comparative study of three types of microbial fuel cell
}

\author{
Ioannis A. Ieropoulos ${ }^{a, b, *}, J$ John Greenman ${ }^{\text {a,b }}$, Chris Melhuish ${ }^{a}$, John Hart $^{c}$ \\ a IAS Lab, CEMS Faculty, University of the West of England, Bristol, UK \\ ${ }^{\mathrm{b}}$ Faculty of Applied Sciences, University of the West of England, Bristol, UK \\ c School of Human and Analytical Sciences, Faculty of Applied Sciences, University of the West of England, Bristol, UK
}

Received 15 October 2004; received in revised form 16 February 2005; accepted 21 March 2005

vived Potter's MFC after scientists had already demonstrated how the enzymes in bacteria oxidise food [12].

The principle of operation of MFCs lies in the extraction

Microbial fuel cells (MFCs) are bio-electrochemical transducers that convert microbial reducing power (generated by the metabolism of organic substrates), into electrical energy [1-5]. They are an alternative to conventional methods of generating electricity, for small-scale applications [6-9].

The link between electricity and metabolic processes in living organisms was first studied in the eighteenth century, when Luigi Galvani observed electricity production in the legs of a frog and first established his theory of 'animal electricity' [10]. In 1910, Potter demonstrated the production of electrical energy (voltage and current) from living cultures of either Escherichia coli or Saccharomyces by using platinum electrodes [11]. This important discovery (the first reported MFC) was forgotten or ignored until 1931 when Cohen re-

\footnotetext{
* Corresponding author. Tel.: +44 117328 3530; fax: +44 1173283960.
} E-mail address: Ioannis2.Ieropoulos@uwe.ac.uk (I.A. Ieropoulos). and transfer of electrons from microbial cells onto the anode electrode. The anode is connected to the cathode via an external electrical circuit through which electrons flow to form the current $(I)$. Electrons travel from the anode (negative) to the cathode (positive) due to the redox potential difference that exists between their dissimilar liquid solutions.

Several microbial species have been reported to release electrons to the anode electrode directly or with the use of their electroactive metabolites [3,4,13-20]. More recently, mixed cultures of bacteria found in sewage sludge have been reported to act in a similar manner, however it has not yet been reported what mechanisms are involved in such an ecosystem [3,21-25]. In their majority, however, bacterial species do not readily release electrons and hence the intervention of synthetic and/or natural compounds termed redox mediators is required. Dye mediators such as neutral red (NR), methy- 
lene blue (MB), thionine (Th), meldola's blue (MelB) and 2-hydroxy-1,4-naphthoquinone (HNQ) have been used with species like Proteus, Enterobacter, Bacillus, Pseudomonas and Escherichia coli to investigate their behaviour and the effect on MFC performance [2,4-6,26-41].

Mediators penetrate the bacterium cell in their oxidised form and interact with reducing agents within the cell (reduced cytochromes, NADH or NADPH) becoming reduced themselves. The reduced mediator is also cell permeable and is capable of diffusing out of the cells to the electrode surface (anode) where it is electrocatalytically oxidised. The oxidised mediator is then free to repeat this cycle. The cycling continually drains off a portion of metabolic reducing power (electrons) to give electrical power at the electrodes. In addition, cell metabolism and mediator interaction release protons in the anodic chamber, which migrate through a proton selective membrane into the cathodic chamber. In one cathode configuration, the protons are taken up by ferricyanide; in another they are consumed by oxygen. Both ferricyanide and oxygen in the presence of electrons donated from the cathode surface react with protons and are reduced to form ferrocyanide or water.

A different type of MFC has been described [3], designed for the treatment of sewage and landfill effluent wastewater. This was based on the sulphate reducing species Desulfovibrio desulfuricans mixed with four other species, namely Proteus vulgaris, Escherichia coli, Pseudomonas aeruginosa and Pseudomonas fluorescens. The role of these other species was to utilise a wide range of sugars and other organic substrates, and convert these into end products including lactate. D. desulfuricans was capable of utilising lactate as its carbon energy source and used sulphate $\left(\mathrm{SO}_{4}\right)$ found in wastewater as its end terminal electron acceptor, which it reduced to sulphide $\left(\mathrm{S}^{2-}\right)[3,18]$. Sulphide was electrochemically active at the anode and was oxidised at the electrode surface, giving electrons and sulphate. This fuel cell gave much higher power density than previous types and required no synthetic exogenous mediators, since the sulphate/sulphide redox couple acted as such.

In later years, Caccavo et al.[42] reported the discovery of a microbial species called Geobacter sulfurreducens that was capable of oxidising acetate and hydrogen. Bond and Lovley [18] reported that this species could produce electricity by forming a monolayer directly on the anode electrode surface and use this as their end terminal electron acceptor in anaerobic respiration. This is a unique ability that can exist in species termed anodophiles such as G. sulfurreducens and Rhodoferax ferrireducens [19].

It is difficult, from published work, to compare the performance of the different types of MFC since different workers have used different conditions and, in particular, different types and surface area ratios of working volumes and electrodes. Moreover, some workers have used gas diffusion cathodes, which use oxygen in air as the oxidant whilst others have used ferricyanide cathodes as a convenient standard catholyte. There have been comparative reviews in the past, in which the authors have attempted to classify MFCs according to the species of microbe and mediator employed and then compare these in terms of power output and longevity [4,14,43-45]. However, due to the lack of vital information from the original authors, these reviews were inconclusive.

The aims of this investigation were to study exemplars of the three fundamentally different MFCs systems, which we term, generation-I (Gen-I), generation-II (Gen-II) and generation-III (Gen-III) using, wherever possible, similar physicochemical controlled conditions to objectively compare their performance. The activity and response of the microorganisms to the different conditions was monitored in terms of fuel cell power output (a measure of bacterial reducing power), longevity of output response and change in anodic $\mathrm{pH}$ levels following the addition of a defined dose of appropriate carbon energy substrate (sucrose or acetate).

\section{Materials and methods}

\subsection{Bacterial strains and their cultivation}

\subsubsection{Gen-I fuel cell}

Escherichia coli (UWE culture collection 17) was maintained on nutrient agar slopes (Oxoid, Basingstoke, UK) and weekly subcultured by transfer on to nutrient agar plates $(\mathrm{Ox}$ oid), at $\mathrm{pH}$ 7.0. The agar plates were incubated at $37^{\circ} \mathrm{C}$ for $18 \mathrm{~h}$ aerobically, and then stored at room temperature. Cell suspensions for experiments were produced by growing $E$. coli in tryptone $\left(10 \mathrm{gl}^{-1}\right)$, yeast extract $\left(5 \mathrm{~g} \mathrm{l}^{-1}\right), \mathrm{K}_{2} \mathrm{HPO}_{4}$ $\left(17.418 \mathrm{gl}^{-1}\right) \mathrm{pH} 7.0$ with sucrose $\left(2 \mathrm{gl}^{-1}\right)$ as the carbon energy $(\mathrm{C} / \mathrm{E})$ source. One litre volume was sterilised by autoclaving at $121^{\circ} \mathrm{C}$ for $15 \mathrm{~min}$.

\subsubsection{Gen-II fuel cell}

Desulfovibrio desulfuricans strain Essex 6 was obtained from the National Collections of Industrial Food and Marine Bacteria Ltd. (NCIMB, Aberdeen, Scotland). Stock cultures were grown and maintained on medium 1249 slopes (Modified Baar's Medium for sulphate reducers) proposed by the American Type Culture Collection for Bacteria and Bacteriophages (ATCC, USA), pH 7.5 at $30^{\circ} \mathrm{C}$ anaerobically. They were weekly subcultured by transfer on to fresh medium agar plates, and stored anaerobically at $30^{\circ} \mathrm{C}$.

Escherichia coli (UWE cc 17), Proteus mirabilis (UWE cc 19), Pseudomonas fluorescens (UWE cc 36) and Pseudomonas aeruginosa (UWE cc 56) were maintained on nutrient agar slopes (Oxoid), at pH 7.0 and weekly subcultured on fresh nutrient agar plates (Oxoid). With the exception of $P$. fluorescens, agar plates were incubated aerobically at $37^{\circ} \mathrm{C}$ and then stored at room temperature. P. fluorescens was both incubated and maintained at room temperature. The bacterial strains used in this line of experiments were adapted to growing in relatively high concentrations of sulphate $(5 \%)$ by sub-culturing with increasing steps of $0.1 \%$ sulphate in nutrient broth and then on to nutrient agar plates with the cor- 
responding sulphate concentration. For experiments, species were grown separately in the nutrient broth with added sucrose $\left(2 \mathrm{gl}^{-1}\right)$ as the $\mathrm{C} / \mathrm{E}$ source. The medium was sterilised by autoclaving prior to inoculation.

\subsubsection{Gen-III fuel cells}

Geobacter sulfurreducens strain PCA was obtained from the ATCC, USA. Stock cultures were grown on ATCC medium 1257 (ETSA medium) broths and agar slopes, $\mathrm{pH}$ 6.8 at $30^{\circ} \mathrm{C}$ anaerobically. The cultures were periodically subcultured on to fresh medium agar plates and stored anaerobically at $30^{\circ} \mathrm{C}$.

\subsection{Estimation of biomass}

Bacterial cultures were typically grown in $4 \times 250 \mathrm{~mL}$ volumes of appropriate broth medium and cells harvested by centrifugation (HS18, MSE Scientific Instruments, Crawley, UK) (6000 rpm for $30 \mathrm{~min}$ ) and then re-suspended in $0.1 \mathrm{M}$ phosphate buffer (Sigma, Dorset, UK). Samples $(0.25 \mathrm{~mL})$ of re-suspended cells were serially diluted (1:1000) until within the linear range of optical density at a wavelength of $660 \mathrm{~nm}$ $\left(\mathrm{OD}_{\lambda}=660 \mathrm{~nm}\right)$. The spectrophotometer used was a Shimadzu UV-1202 and an OD of 1 was considered to be equivalent to $1200 \mu \mathrm{g}$ dry weight cells per $\mathrm{mL}$ [46]. The $660 \mathrm{~nm}$ wavelength was chosen to allow the comparison with previous work [40].

\subsection{MFC design and operation}

The MFCs comprised two (anode and cathode) $25 \mathrm{~mL}$ Perspex chambers with dimensions $h=6 \mathrm{~cm}, w=5 \mathrm{~cm}$, $l=1.5 \mathrm{~cm}$, open on one side and with two holes on top, as described by Bennetto 1990 [6]. They were assembled using $5 \mathrm{~mm}$ stainless steel studding, washers and nuts, and physically separated by a Nafion ${ }^{\circledR}$ proton exchange membrane (Merch Ltd., Lutterworth, UK) with a $30 \mathrm{~cm}^{2}$ surface area. Each chamber contained a folded sheet of carbon fibre veil $\left(20 \mathrm{~m}^{2} \mathrm{~g}^{-1}\right)$ (PRF Composite Materials Poole, Dorset, UK) as the electrode with a resistivity of $5 \Omega \mathrm{m}$ in the machine direction and $9 \Omega \mathrm{m}$ in the cross direction. The folded electrodes were pierced with a $5 \mathrm{~cm}$ long nickel-chrome wire coming out of one of the two top holes to provide the connection points for the external circuit. The electrode conformation was such that $180 \mathrm{~cm}^{2}$ surface area of carbon veil was 'folded down' to $5 \mathrm{~cm}^{2}$, in order to reduce the resistance of the material, and hence reduce the internal resistance of the fuel cell. The analytical form of a MFC is shown below in Fig. 1.

\subsection{Data capture}

Electrode output was measured in millivolts [mV] against time. This was achieved by linking the MFCs to the serial communications port of a desktop pc via an eight-channel RS232 interface connected to an ADC-16 A-D converter

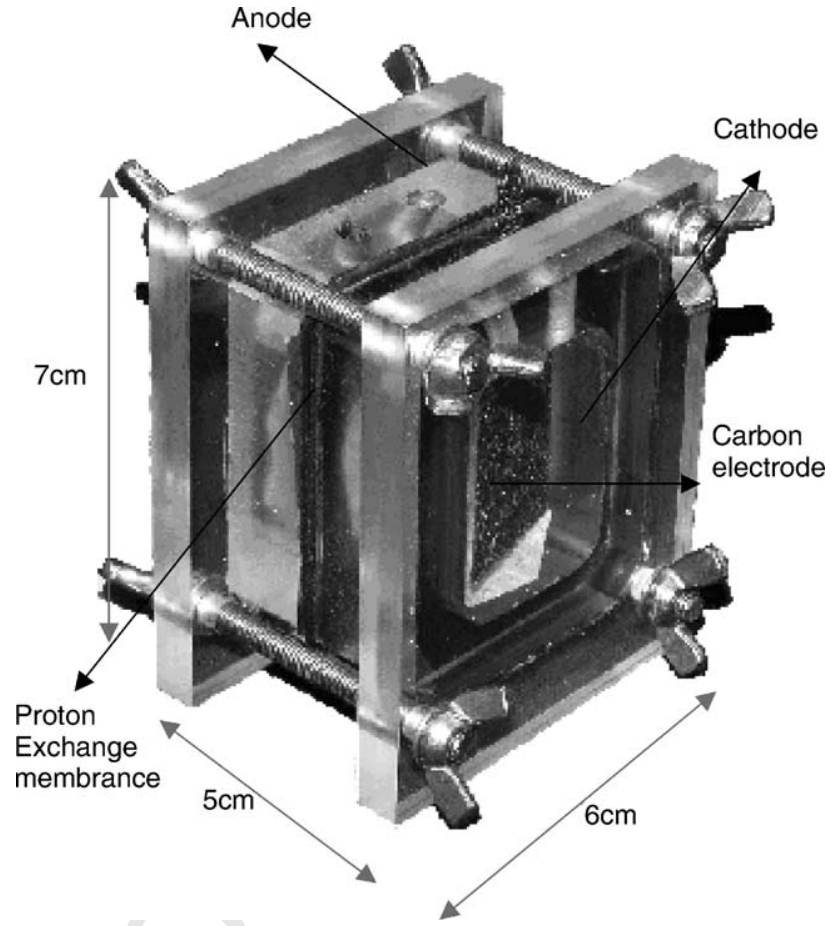

Fig. 1. Analytical form of MFC used in these comparative experiments.

(Pico Technology Ltd., Cambridgeshire, UK). Two such systems were configured for experiments involving more than eight MFCs.

Real time data was recorded using PicoLog ${ }^{\circledR}$ vesion 5.09.4 recorder software and retrieval of the data was performed using the PicoLog ${ }^{\circledR}$ vesion 5.09.4 player software (Pico Technology).

\subsection{Background current}

All the three types of MFC were set up with each containing the same electrode type/shape/size and concentration of catholyte. The anolytes were made according to each generation's composition, but in the absence of microbial cells and $\mathrm{CE}$ source, and were monitored so as to establish the baseline of the chemical redox reactions.

\subsection{Calculation of power output and coulombic efficiency}

The current $I$ in Amperes (A) was calculated using Ohm's law, $I=V / R$, where $V$ is the measured voltage in Volts $(\mathrm{V})$ and $R$ is the known value of the external load resistor in Ohms $(\Omega)$. The external load value used for the experiments was $10 \mathrm{k} \Omega$. From this it is possible to calculate the power output $P$ in watts (W) of the MFCs by taking the product of the voltage and current, i.e. $P=I \times V$. Current density was calculated using $I=V / \alpha R$, where $\alpha$ is the electrode surface area.

Output expressed in terms of electrons per unit area of electrode, was calculated using $1[\mathrm{C}]=1[\mathrm{~A}] \times 1[\mathrm{~s}]$, $1[\mathrm{C}]=6.24 \times 10^{18} \mathrm{e}^{-}$and $1 \mathrm{~mol}=6.02 \times 10^{23} \mathrm{e}^{-}$and taking 
into consideration the electron yield from each of the substrates used. Output expressed in terms of electrons per dry weight cell was also calculated using the above formulae.

The power output due to the microbial cells was obtained by subtracting the MFC power recorded in the absence of microbes (background current) from that recorded in the presence of cells.

\subsection{Internal resistance $\left(R_{I N T}\right)$}

Internal resistance was calculated from: $R_{\mathrm{INT}}=\left(V_{\mathrm{o} / \mathrm{c}} / I_{\mathrm{L}}\right)$ $-R_{\mathrm{L}}$, where $V_{\mathrm{o} / \mathrm{c}}$ is the open-circuit of the MFC, $I_{\mathrm{L}}$ is the current under a load and $R_{\mathrm{L}}$ is the value of the load resistor. The equation is derived from applying Kirchoff's voltage law to a circuit where a power source is connected to a known load. Due to the fact that both the $V_{\mathrm{o} / \mathrm{c}}$ and $I_{\mathrm{L}}$ were necessary to perform the calculations, two MFCs were employed, in the cases of Gen-I and -II, where one of them was continuously under load and the other was open-circuit. For Gen-III experiments, $R_{\mathrm{INT}}$ was calculated by connecting the MFC to the same load for a period of time (to ensure electrode colonisation) and then disconnecting to open-circuit for measurements to be taken.

\subsection{Catholyte composition}

The catholyte consisted of $\mathrm{K}_{3} \mathrm{Fe}[\mathrm{CN}]_{6}$ (III) $\left(32.88 \mathrm{gl}^{-1}\right)$ mixed with $\mathrm{K}_{2} \mathrm{HPO}_{4}\left(87.09 \mathrm{~g}^{-1}\right)$, with the $\mathrm{pH}$ adjusted to 7.5. For the purpose of this investigation, the catholyte composition was the same for all experiments.

\subsection{Anolyte composition}

For Gen-I experiments comparing mediators, the anolyte consisted of $\mathrm{K}_{2} \mathrm{HPO}_{4}$ buffer $\left(87.09 \mathrm{~g} \mathrm{l}^{-1}\right)$ plus mediator at $0.1 \mathrm{mM}$ final concentration, $\mathrm{pH}$ 7.5. These were MB $\left(0.0319 \mathrm{gl}^{-1}\right)$, HNQ $\left(0.0174 \mathrm{~g}^{-1}\right)$, NR $\left(0.0288 \mathrm{gl}^{-1}\right)$, MelB $\left(0.0379 \mathrm{~g}^{-1}\right)$, Th $\left(0.0287 \mathrm{gl}^{-1}\right)$. For these experiments sucrose was used as a substrate at $29.3 \mathrm{mM}(1 \%$ $(w / v)$ ) final concentration (C/E excess conditions for the duration).

For comparing Gen-I with other generation MFCs the anolyte consisted of MB and $\mathrm{K}_{2} \mathrm{HPO}_{4}$ (as above) with sucrose $1.17 \mathrm{mM}(0.04 \%(\mathrm{w} / \mathrm{v}))$, which was shown to be C/E limiting by 10 days of operation.

For Gen-II MFCs homogenised clay $\left(250 \mathrm{~g}^{-1}\right)$ and slate $\left(250 \mathrm{~g}^{-1}\right)$, particles $(2.5 \%(\mathrm{w} / \mathrm{v})$ final concentration in both the cases) mixed with $\mathrm{KH}_{2} \mathrm{PO}_{4}\left(68.045 \mathrm{~g} \mathrm{l}^{-1}\right)$ were used in the anolyte. These were derived from garden clay and pulverised garden slate, and were used to provide 'sediment' at the bottom of the half-cell. Mixtures were set at $\mathrm{pH} 7.5$ prior to sterilisation by autoclaving.

For Gen-III MFCs, the anolyte composition was $\mathrm{K}_{2} \mathrm{HPO}_{4}$ $\left(87.09 \mathrm{~g}^{-1}\right)$ at $\mathrm{pH}$ 6.8. In contrast to the other fuel cells, the CE source for Gen-III MFCs was acetate at a final concentration of $5 \mathrm{mM}(0.04 \%(\mathrm{w} / \mathrm{v}))$.
Table 1

Averaged power output, final $\mathrm{pH}$ value and calculated internal resistance for Gen-I MFC for five different mediators

\begin{tabular}{lllc}
\hline Mediator & $P_{\text {ave }}(\mu \mathrm{W})$ & $\mathrm{pH}$ shift & $R_{\mathrm{INT}}(\mathrm{k} \Omega)$ \\
\hline MB & 31.77 & -0.4 & 2.37 \\
HNQ & 29.83 & -0.3 & 4.51 \\
Th & 28.84 & -0.3 & 4.09 \\
MelB & 26.12 & -1.3 & 3.52 \\
NR & 12.73 & -0.6 & 11.16 \\
\hline
\end{tabular}

\section{Results}

\subsection{Synthetic mediator investigation}

Different synthetic mediators were used in Gen-I MFCs to investigate their performance in both electron extraction and speed of response. Table 1 shows the average power output, $\mathrm{pH}$ values and internal resistance values for the five mediators in Gen-I MFCs over 5 days. MB produced the highest average power whilst NR produced the lowest, approximately, $40 \%$ that of $\mathrm{MB}$. The final $\mathrm{pH}$ values were close to neutral with the exception of MelB, which was more acidic at $\mathrm{pH}$ 6.2. The calculated values for $R_{\mathrm{INT}}$ showed that MB had the lowest internal resistance value whilst NR had the highest.

\subsection{Comparative results from the three $M F C$ generations}

The average power output data over the first 10 days is shown in Fig. 2 and summarised in Table 2, during which Gen-II gave the highest output. The time taken for the power output of each MFC type to reach the baseline value due to substrate depletion was different (10, 15 and 25 days for GenI, -II and -III, respectively). Couloumbic efficiency, electron

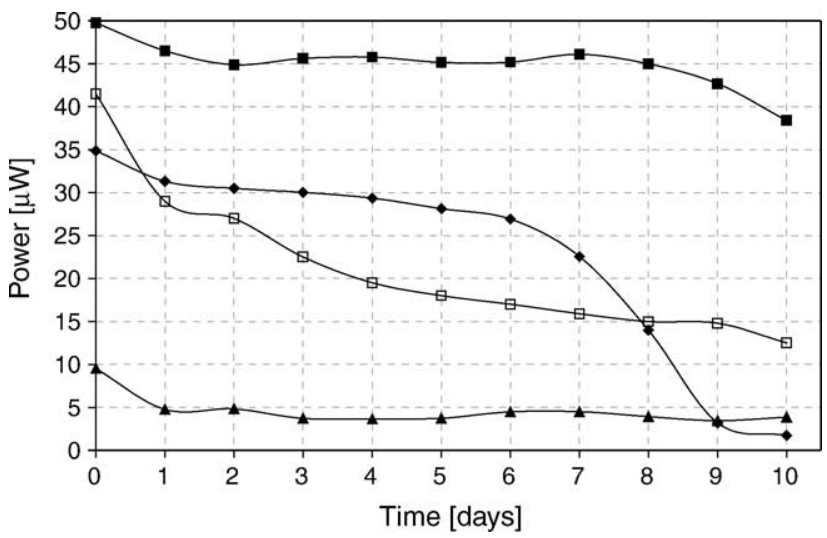

Fig. 2. Power output from different types of MFC (first 10 days). Circuit load was $10 \mathrm{k} \Omega$ for equal load comparison (closed symbols) and $1 \mathrm{k} \Omega$ for Gen-III load optimisation (open symbols). Substrate for Gen-I and -II was sucrose, and for Gen-III was acetate at the same gram weight concentration $(0.04 \%$ $(\mathrm{w} / \mathrm{v}))$, biomass was $\mathrm{OD}=15$ [abs], catholyte was $\mathrm{K}_{3} \mathrm{Fe}^{3-}[\mathrm{CN}]_{6}$ at $0.1 \mathrm{M}$ concentration and the electrode surface area was $180 \mathrm{~cm}^{2}$. The synthetic mediator used in the Gen-I MFC for this comparative experiment was MB Key to symbols: Gen-I $(\bullet)$, Gen-II $(\mathbf{\square})$, Gen-III-10 k $\Omega(\mathbf{\Delta})$ and Gen-III-1 k $\Omega$ $(\square)$. 
Table 2

Average current and power output for the three MFC generations, with calculated $R_{\mathrm{INT}}$, current density $\left(I_{\mathrm{d}}\right)$, coulombic yield $(C)$ and efficiency $\left(\eta_{\mathrm{C}}\right)$

\begin{tabular}{|c|c|c|c|c|}
\hline & Gen-I $(10 \mathrm{k} \Omega)$ & Gen-II $(10 \mathrm{k} \Omega)$ & Gen-III (10 k $\Omega)$ & Gen-III $(1 \mathrm{k} \Omega)$ \\
\hline$P_{\text {ave }}(\mu \mathrm{W})$ & 22.27 & 45.50 & 4.62 & 21.15 \\
\hline$I_{\text {ave }}(\mu \mathrm{A})$ & 44.05 & 67.41 & 21.16 & 106.76 \\
\hline$I_{\mathrm{d}}\left(\mathrm{mA} / \mathrm{m}^{2}\right)$ & 2.44 & 3.74 & 1.17 & 5.93 \\
\hline$C$ & 38.05 & 87.36 & 45.71 & 92.24 \\
\hline$e\left(\mathrm{~cm}^{2}\right)$ & $1.32 \times 10^{18}$ & $3.02 \times 10^{18}$ & $1.58 \times 10^{18}$ & $3.19 \times 10^{18}$ \\
\hline$e^{-}(\mu \mathrm{g})$ & $0.53 \times 10^{15}$ & $1.21 \times 10^{15}$ & $33.72 \times 10^{15 a}$ & $68.03 \times 10^{15 a}$ \\
\hline \multirow[t]{2}{*}{ Maximum yield (mmol) } & \multicolumn{2}{|c|}{ Sucrose } & \multicolumn{2}{|c|}{ Acetate } \\
\hline & \multicolumn{2}{|c|}{1.4035} & \multicolumn{2}{|c|}{1} \\
\hline$\eta_{\mathrm{C}}(\%)$ & 28.12 & 64.52 & 47.38 & 95.61 \\
\hline $\mathrm{pH}$ shift & -0.4 & 0 & 0 & 0 \\
\hline$R_{\mathrm{INT}}(\mathrm{k} \Omega)$ & 7.86 & 1.87 & 4.18 & 1.10 \\
\hline
\end{tabular}

Also shown in Table 2 are values for the number of electrons $\left(e^{-}\right)$per electrode unit surface and per dry weight cells. In the case of Gen-III, analytical data is shown for both optimal and sub-optimal external loading conditions

a Geobacter sulfurreducens electrode colonisation was taken to be $0.047 \mathrm{mg} / \mathrm{cm}^{2}$ from Bond and Lovley [18].

yield per electrode unit area and per dry weight cell were calculated on the basis of complete substrate depletion (total duration), and in these cases Gen-III gave the highest values. In terms of $\mathrm{pH}$ values, Gen-I MFC showed a decrease of 0.4 $\mathrm{pH}$ units over the 10-day period, however Gen-II and -III showed no $\mathrm{pH}$ change after the period of substrate depletion (Table 2). The lowest value of $R_{\text {INT }}$ was given by Gen-II MFC, followed by Gen-III and Gen-I, respectively. Also shown in Table 2 is the current density $\left(\mathrm{A} / \mathrm{m}^{2}\right)$ for each of the three MFCs, based on average output.

The effect of changing the circuit load resistance on GenIII performance was studied by replacing the $10 \mathrm{k} \Omega$ load by a $1 \mathrm{k} \Omega$ resistor on an otherwise identical MFC with respect of other parameters. Analytical data from this experiment are also shown in Table 2. The average power output over the same 10-day duration is shown in Fig. 4. As it can be seen, this MFC produced on average a power output five times higher than that produced using the sub-optimal $(10 \mathrm{k} \Omega)$ load.

\section{Discussion}

Three fundamentally different types of MFC, which are categorised by the way electron transfer to the anode is achieved, have been compared. These systems are classified as generations, according to their historical development and initial descriptions in the scientific literature.

Gen-I MFCs are characterised by their use of a synthetic mediator to couple cellular electron exchange (reducing power) to electron abstraction at the anode. Using E. coli as the standard exemplar of heterotrophic species commonly employed in Gen-I MFCs, we compared the effects of five different mediators in otherwise identical systems and found power to improve in the order of NR, MelB, Th, HNQ and MB.

In an MFC using a standardised cathodic system, there exist two distinct redox processes to be considered: interaction between the redox mediator and the biological reducing systems in the bacterial cell, and the interaction between the anode and the cathode. Although mediators may well differ in their abilities to penetrate the bacterial cytoplasmic membrane in their oxidised or reduced form (permeability or diffusability), the most important difference is their standard redox potential (redox equilibrium). Within a MFC system, the lower the redox of the anode compared to the cathode, the higher the output open-circuit voltage (all other factors being equal). This is an indication of the force with which electrons will flow. The synthetic mediator NR has the lowest redox (highest negative value $E_{0}^{\prime}=-0.325 \mathrm{mV}$ ), and on this basis would be expected to produce the highest voltage and current. However, the data shows this not to be the case. This suggests the possibility that NR is not the most efficient mediator when competing for electron transfer within the cell. The redox difference between the principle redox couples within the cell (cytochromes, NADH, NADPH, glutathione) and the highly negative NR may be too small to allow the efficient electron transfer. In contrast, $\mathrm{MB}$ which has a less negative redox $\left(E_{0}^{\prime}=-10 \mathrm{mV}\right)$ may be expected to produce a lower electrode open-circuit voltage than NR, yet is clearly superior in giving the MFC greater power output. This suggests that $\mathrm{MB}$ is more efficient at the cell interaction stage. To work efficiently, anodic mediators must possess a standard redox potential $\left(E_{0}^{\prime}\right)$ that is positive enough compared to the biological electron carrier (e.g. reduced cytochromes or NADH) to extract electrons from, but negative enough compared to the anode electrode, to be oxidised at its surface. In this way, the electron exchange between biological reductants and artificial oxidants that would not naturally occur is indirectly achieved.

The internal resistance $\left(R_{\mathrm{INT}}\right)$ in MFCs can be affected by the anolyte and catholyte composition and $\mathrm{pH}$, electrode material and structure, electrode polarisation and the microbes, which are by nature resistive. An MFC will have a high $R_{\mathrm{INT}}$ if the electron flow $\left(I_{\mathrm{L}}\right)$ is low compared to the force with which electrons can flow through the system $\left(V_{\mathrm{o} / \mathrm{c}}\right)$. In the case of NR the $V_{\mathrm{o} / \mathrm{c}}$ is high $\left(V_{\mathrm{MFC}} \approx 0.8 \mathrm{~V}\right)$ when placed against the 
ferricyanide cathode $\left(E_{0}^{\prime}=-0.436 \mathrm{mV}\right)$ but the $I_{\mathrm{L}}$ is low due to the reasons mentioned earlier, hence the higher $R_{\mathrm{INT}}$ when compared to that of other mediators. This means that the NR MFC has a higher tendency to oppose the flow of electrons produced within the system. It was also observed that $R_{\mathrm{INT}}$ was affected by operation time; the longer the experiments were run, the higher it would become. The changes with time prevent the use of the polarisation curve method $[20,47]$ to compare power outputs across a range of resistors, a method, which requires steady-state conditions. The changes over time probably reflect a combination of mediator degradation, microbial exhaustion, and acid waste build-up or substrate depletion. For Gen-II MFCs, $R_{\mathrm{INT}}$ is less affected through operation, giving a more consistent performance over time.

From the initial experiments comparing five different mediators in the Gen-I MFCs, it was decided to use MB as the mediator in the experiments comparing the three different MFC types. As it can be seen from Fig. 2, under the same external circuit load conditions, the highest average power and current output was given by the Gen-II, followed by the Gen-I MFC, both fed with sucrose. The lowest power output was produced by the Gen-III MFC fed with acetate. The coulombic yield was calculated based on the average current and complete substrate depletion, which is the time period taken for the output to reach the baseline. In this case the Gen-II MFC gave the highest yield with the Gen-III MFC being the second best due to the long time taken for its output to reach the baseline. The coulombic efficiency was calculated on the basis of maximum substrate yield, with Gen-II being the most efficient followed by the Gen-III and -I, respectively. The same order was observed when output was expressed as the number of electrons per electrode surface area.

For Gen-III MFCs, it has been shown [19] that the $G$. sulfurreducens anodophile forms a monolayer on to the electrode surface, suggesting that the number of microorganisms engaged in the electron transfer is only a small proportion of the total inoculated into the anodic compartment. This was validated in our studies by periodic removal of the anolyte and replacement with only acetate and buffer. In these cases the power output remained unaffected apart from an initial small fluctuation due to fluid agitation. Under the conditions of replaced anolyte, the output expressed in terms of electrons per dry weight of cells was very much higher for the Gen-III system (Table 2). This suggests that the properties of such a system are far different to those of the others and will have to be addressed in a different way when considering things like scaling-up (or down), electrode surface area to volume ratio, optimum circuit load and dilution rate in the case of a continuous flow system.

In the experiments using equal external load $(10 \mathrm{k} \Omega)$, the power output from Gen-III MFCs was not as high as previously reported [19]. One reason for this could be the suboptimal poise potential of the anode electrode. The poise potential can be changed in two different ways: (a) by using a potentiostat and (b) by varying the external load. Using the former method, Chaudhury and Lovley [19] showed that a better conversion rate of acetate to electrons was achieved when the electrode was poised using a potentiostat at $+0.2 \mathrm{~V}$. In our experiments, the effect of changing the external load (second method) was studied. The $10 \mathrm{k} \Omega$ resistor value was initially chosen after optimising the power output from Gen-I MFCs (data not shown) and hence the same value resistor was used for all the three generations throughout this line of experiments for comparative purposes. A significant improvement was observed using a $1 \mathrm{k} \Omega$ external load instead of a $10 \mathrm{k} \Omega$ (Table 2). Data from Chaudhury and Lovley [19] taken together with our results with the two different resistor values suggest that there is an inverse relationship between the power output and the value of the external load resistor between the values of $0.5-10 \mathrm{k} \Omega$.

The abstraction of electrons from substrates in a Gen-I type MFC using artificial mediators is an accidental contingent property of the microorganisms and their interaction with the mediator. In contrast, D. desulfuricans used in Gen-II MFCs is capable of reducing the sulphate to sulphide, as part of its natural metabolism. Furthermore, sulphate/sulphide can be found naturally in wastewater. Clearly this type of fuel cell could be operated in continuous mode, providing sulphate or sulphide was present in the input stream. Although sulphate/sulphide would be present in the output stream, this would be more acceptable than dye mediators since it is otherwise present as a natural consequence of waste production. Due to the fact that the mediator is natural rather than synthetic, such MFCs are referred to as second generation (Gen-II) MFCs.

To be of practical use giving power output over long periods of time (months/years) MFCs will have to be converted to continuous flow and employ cathodic half-cells that can negate the need for replenishment. The latter can be achieved by exploiting oxygen from free instead of ferricyanide that requires periodic replenishment. In such systems, substrate and other nutrients will be continuously supplied to the bacteria and furthermore, there will be no waste product accumulation as these will be constantly driven out of the system. Designing MFCs to operate in a continuous mode is a challenge that will have to be addressed according to the type of MFC under consideration.

Due to the difficulty in producing, maintaining and discarding artificial mediators, Gen-I MFCs are unlikely to have an impact in future developments of this kind. On the other hand, Gen-II and -III MFCs may be used advantageously in wastewater treatment and power generation.

\section{References}

[1] Bennetto HP. Microbial fuel cells. In: Life chemistry reports. London: Harwood Academic; 1984. p. 363-453. 
[2] Stirling JL, Bennetto HP, Delaney GM, Mason JR, Roller SD, Tanaka K, et al. Microbial fuel cells. J Biochem Soc Trans 1983;11:451-3.

[3] Habermann W, Pommer E-H. Biological fuel cells with sulphide storage capacity. J Appl Microbiol Biotechnol 1991;35:128-33.

[4] Palmore GTR, Whitesides GM. Microbial and enzymatic biofuel cells. In: Enzymatic conversion of biomass for fuels production. Oxford University Press; 1994. p. 271-90.

[5] Allen RM, Bennetto HP. Microbial fuel cells. Electricity production from carbohydrates. J Appl Biochem Biotechnol 1993;39-40:27-40.

[6] Bennetto HP. Electricity generation by microorganisms. Biotechnol Ed 1990;1:163-8.

[7] Wilkinson S. Gastronome-a pioneering food powered mobile robot. In: Proceedings of the IASTED International Conference on Robot \& Appl.;2000. paper no. 318-037.

[8] Ieropoulos I, Greenman J, Melhuish C. Imitating metabolism: energy autonomy in biologically inspired robotics. In: Proceedings of the AISB'03, 2nd Int Symp. Imitat Animals and Artifacts. 2003. p. $191-4$.

[9] Ieropoulos I, Melhuish C, Greenman J. Artificial metabolism: towards true energetic autonomy in artificial life. In: Proceedings of the 7th ECAL. 2003. p. 792-9.

[10] Piccolino M. Animal electricity and the birth of electrophysiology: the legacy of Luigi Galvani. Brain Res Bull 1998;46:381-407.

[11] Potter MC. Electrical effects accompanying the decomposition of organic compounds. Proc R Soc Ser B 1912;84:260-76.

[12] Cohen B. The bacterial culture as an electrical half-cell. J Bacteriol 1931;21:18.

[13] Allen MJ. The electrochemical aspects of some biochemical systems. IX. The anomalous behaviour of $E$. coli with mixed substrates. J Electrochim Acta 1966;11:1503-8.

[14] Lewis K. Biochemical fuel cells. Bacteriol Rev 1966;30:101-13.

[15] Karube I, Matsunaga T, Tsuru S, Suzuki S. Biochemical fuel cell utilizing immobilized cells of Clostridium butyricum. Biotechnol Bioeng 1975;19:1727-33.

[16] Tanisho S, Kamiya N, Wakao N. Microbial fuel cell using Enterobacter aerogenes. J Bioelectrochem Bioenerg 1989;21:25-32 [A section of J Electroanal Chem and constituting vol. 275].

[17] Cooney MJ, Roschi E, Marison IW, Comminellis Ch, von Stockar U. Physiologic studies with the sulfate-reducing bacterium Desulfovibrio desulfuricans: evaluation for use in a biofuel cell. Enzyme Microb Technol 1996;18:358-65.

[18] Bond DR, Lovley DR. Electricity production by Geobacter sulfurreducens attached to electrodes. Appl Environ Microbiol 2003;69:1548-55.

[19] Chaudhuri SK, Lovley DR. Electricity generation by direct oxidation of glucose in mediatorless microbial fuel cells. Nat Biotechnol 2003;21:1229-32.

[20] Jang JK, Pham TH, Chang IS, Kang KH, Moon H, Cho KS, et al. Construction and operation of a novel mediator- and membrane-less microbial fuel cell. Process Biochem 2003;39:1007-12.

[21] Park DH, Zeikus JG. Improved cell and electrode designs for producing electricity from microbial degradation. Biotechnol Bioeng $2003 ; 81: 348-55$

[22] Rabaey K, Lissens G, Siciliano SD, Verstraete W. A microbial fuel cell capable of converting glucose to electricity at high rate and efficiency. Biotechnol Lett 2003;25:1531-5.

[23] Liu H, Ramnarayanan R, Logan BE. Production of electricity during wastewater treatment using a single chamber microbial fuel cell. Environ Sci Technol 2004;38:2281-5.

[24] Liu H, Logan BE. Electricity generation using an air-cathode single chamber microbial fuel cell in the presence and absence of a proton exchange membrane. Environ Sci Technol 2004;38:4040-6.

[25] Oh S, Min B, Logan BE. Cathode performance as a factor in electricity generation in microbial fuel cells. Environ Sci Technol 2004:38:4900-4.

[26] Bennetto HP, Stirling JL, Tanaka K, Vega CA. Anodic reactions in microbial fuel cells. Biotechnol Bioeng 1983;XXV:559-68.
[27] Adreleanu I, Margineanu D-G, Vais H. 594-Electrochemical conversion in biofuel cells using Clostridium butyricum or Staphylococcus aureus oxford. J Bioelectrochem Bioenerg 1983;11:273-7 [A section of $\mathrm{J}$ Electroanal Chem and constituting vol. 156].

[28] Tanaka K, Vega CA, Tamamushi R. 591-Mediating effects of ferric chelate compounds in microbial fuel cells. J Bioelectrochem Bioenerg 1983;11:135-43 [A section of J Electroanal Chem and constituting vol. 156].

[29] Tanaka K, Vega CA, Tamamushi R. 612bis-thionine and ferric chelate compounds as coupled mediators in microbial fuel cells. J Bioelectrochem Bioenerg 1983;11:289-97 [A section of J Electroanal Chem and constituting vol. 156].

[30] Roller SD, Bennetto HP, Delaney GM, Mason JR, Stirling JL, Thurston CF. Electron-transfer coupling in microbial fuel cells. 1. Comparison of redox-mediator reduction rates and respiratory rates of bacteria. J Chem Tech Biotechnol 1984;34B:3-12.

[31] Delaney GM, Bennetto HP, Mason JR, Roller SD, Stirling JL, Thurston CF. Electron-transfer coupling in microbial fuel cells. 2. Performance of fuel cells containing selected microorganism-mediator-substrate combinations. J Chem Tech Biotechnol 1984;34B:13-27.

[32] Lithgow AM, Romero L, Sanchez IC, Souto FA, Vega CA. Interception of the electron transport chain in bacteria with hydrophilic redox mediators. 1. Selective improvement of the performance of biofuel cells with 2,6-disulphonated thionine as mediator. J Chem Research (S) 1986:178-9.

[33] Thurston CF, Bennetto HP, Delaney GM, Mason JR, Roller SD, Stirling JL. Glucose metabolism in a microbial fuel cell. Stoichiometry of product formation in a thionine-mediated Proteus vulgaris fuel cell and its relation to coulombic yields. J Gen Microbiol 1985;131:1393-401.

[34] Bennetto HP, Delaney GM, Mason JR, Roller SD, Stirling JL, Thurston CF. The sucrose fuel cell: efficient biomass conversion using a microbial catalyst. Biotechnol Lett 1985;7:699_ 704.

[35] Vega CA, Fernandez I. 951-Mediating effect of ferric chelate compounds in microbial fuel cells with Lactobacillus plantarum, Streptococcus lactis and Erwinia dissolvens. J Bioelectrochem Bioenerg 1987;17:217-22 [A section of J Electroanal Chem and constituting vol. 231].

[36] Bennetto HP, Delaney GM, Mason JR, Roller SD, Stirling JL, Thurston CF. An electrochemical bioreactor for treatment of carbohydrate wastes and effluents. In: Alternative energy sources, VII 4, bioconversion/hydrogen. New York, NY: Hemisphere Publishing Corporation; 1987. p. 143-57.

[37] Halme A, Zhang X, Rintala N. Monitoring and control of a bacteria fuel cell process by color analysis. In: Proceedings of the 7th International Conference on Comp Appl on Biotechnol. 1998. p. 4627.

[38] Kim N, Choi Y, Jung S, Kim S. Effect of initial carbon sources on the performance of microbial fuel cells containing Proteus vulgaris. Biotechnol Bioeng 2000;70:109-14.

[39] Kim N, Choi Y, Jung S, Kim S. Development of microbial fuel cells using Proteus vulgaris. Bull Korean Chem Soc 2000;21:44-8.

[40] Park DH, Zeikus JG. Electricity generation in microbial fuel cells using neutral red as an electronophore. Appl Environ Microbiol 2000;66:1292-7.

[41] Park DH, Zeikus JG. Impact of electrode composition on electricity generation in a single-compartment fuel cell using Shewanella putrefaciens. Appl Microbiol Biotechnol 2002;59:58-61.

[42] Caccavo F, Debra JR, Lonergan J, Lovley DR, Davis M, Stolz JF, et al. Geobacter sulfurreducens sp. nov., a hydrogen- and acetateoxidising dissimilatory metal-reducing microorganism. Appl Environ Microbiol 1994;60:3752-9.

[43] Wingard LB, Shaw CH, Castner JF. Bio-electrochemical fuel cells. Enzyme Microbiol Technol 1982;4:137-42. 
[44] Halme A, Zhang X-C, Ranta A. Study of biological fuel cells. In: Small fuel cells and battery technologies-2nd Ann Int Conf for use in portable. app. 26-28 April. 2000.

[45] Shukla AK, Suresh P, Berchmans S, Rajedran A. Biological fuel cells and their applications. Curr Sci 2004;87:45568.
[46] Neidhardt FC, Ingraham JL, Schaechter M. Growth of cells and populations. In: Physiology of the bacterial cell: a molecular approach. Sunderland, MA: Sinauer Associates; 1990. p. 197-225.

[47] Gil GC, Chang IS, Kim BH, Kim M, Jang JK, Park HS, et al. Operational parameters affecting the performance of a mediator-less microbial fuel cell. Biosens Bioelectron 2003;18:327-34. 